\title{
Commemorating the First World War in Britain : A Cultural Legacy of Media Remembrance
}

\author{
MAGGIE ANDREWS - University of Worcester, UK
}

\begin{abstract}
One of the often-overlooked legacies of the First World War is how the conflict established the media's role in remembrance. In the years that have followed, media's circulation of iconic images of national and local commemoration have enabled individuals to engage with public remembrance. This article takes a historical approach to First World War remembrance in Britain, looking at how the practices and meaning of remembrance became established, although they were never fixed but instead constantly shifting, reinvented and contested. They are also gendered, in remembrance, as in war, women, are often seen as to be playing supportive roles; yet within media texts, women have always found spaces to exert influence over who is remembered and how, as memories jostle for prominence.
\end{abstract}

\section{KEYWORDS}

media; remembrance; commemoration; First World War; gender

The First World War coincided with the rise of the tabloid newspapers, film establishing itself as a popular medium and just preceded radio entering British homes (Williams, 2009; Curran,2012). In thelast 100 years traditional and then new media have played a major role in commemorative activities (Schwartz, 1991, Baer, 2001; Landsberg, 2004; Keren and Herwig, 2009; Neiger, et al., 2011), enabling the national calendar and iconography of poppies, parades and wreath laying at the Cenotaphto saturate the British cultural landscape of remembrance (Mosse, 1991; Winter, 1998, 2006a,b; Gregory, 2014). These national icons of remembrance are interwoven with local media's portrayals of remembrance providing the building blocks for individual, local, community and national constructions of both cultural memories and identities. Practices of remembrance are historically, culturally and nationally specific. England, Scotland and Wales share a common legacy of involvement in two conflicts in which conscription, bombing and mass mobilization of the economy occurred but the landscape was not shaped byinvasion or occupation. In the inter-war years these countries' shared media operated as what Pierre Nora terms 'sites of memory', spaces and places 'where memory crystallizes and secretes itself' (1989:7). Shared remembrance could be seen to operate as 'signs of distinction and of group membership' (1989: 12) but audiences invest media texts with their own meanings (Ang, 2006; Cover, 2006). To appeal to audiences, media remembrance has to be receptive to the ideas and values of those who consume it. Thus any collective memory that media texts offer as King suggests is, 'constantly revised' (2010:3) contested and ever-changing, shaped by and shaping the culture in which it isenacted. 
Mostrecently, against a backdrop of a Britain divided by austerity and Brexit(Ashcroftand Bevir, 2016, Hobolt, 2016; Berry, 2017), with contested ideas of national identity and pockets of ultra-nationalism, 1 heated discussion has occurred on daytime television and in social media challenging and questioning practices of remembrance. When and whether to wear a red poppy is a touch paper for this conflict. In 2017, the publichouse chain Weatherspoons was the subject of a Twitter-storm when a tweet incorrectly announced they had banned staff from wearing poppies. Hancock (2017) has documented theangrypostings and threats of boycotts and demonstrations that occurred when it was suggested this ban was a consequence of 'multiculturalism'. The company quickly denied they had any intention of banning poppies, but the fake-news was credible because it followed more than a decade of controversy surrounding the wearing of poppies. This seemingly private decision became the focus of a national media debate when Channel 4 newscaster JonSnow explained his reticence to wear a poppy on air and expressed his unease about what he termed 'poppy fascism' (2006); a charge that was given some credibility by viewers' furious response when Evan Davis and Sienna Miller appeared on BBC television without a poppy in 2015. Recent studies have emphasized the scope of new media to contest authoritative versions of the past (Hess, 2007; Pentzold, 2011; Zhao and Liu, 2015) but a historical analysis suggests such controversies are an intrinsic element of media remembrance. Where once these debates were played out on the pages of local and national newspapersnow they take place in social mediaforums. The ferocity of theseexchanges, in the wake of the 'memory boom' of the late twentieth century with its multiple causations (Winter,2001, 2007), is a reminder that although remembrance and the production of cultural memories mayseem an institutionalized and intrinsic part of British culture, theylikeall popular culture have always been contested (Hall,1981), shifting, complex, and contradictory. This process of creating and contesting memories of the First World War begun during the course of the war itself.

Cultures and practices of remembrance are not all embracing, not all deaths in the First World War are commemorated. JackCornwell was posthumously awarded the Victoria Cross after his death at the Battle of Jutland in 1916; school logbooks record children collecting for his Memorial Fund that year (WAAS D836). But the 55 young boys under 16 who died in the Minnie Pitt disaster in Staffordshire in 1918 (Lamb, 1994), mining coal needed for power warships and factories making munitions are largely forgotten; their history of child labour is not a palatable past. The selectivity of whois remembered istangled up with gender, like war itself, part of a process of continuouslyshifting constructions of masculinity and femininity; women were 
offered supportive roles: 'as mother, sweetheart, wife, sister or daughter' (Huston, 1983:225) in First World War propaganda and in commemoration of the conflict, often relegated to supportive roles as widows, mothers or sisters mourning their men. Adrian Gregory has pointed out, it was women who predominantly sold poppies in the inter-waryears and it was for this role that the British Legion women's section was set up (Gregory, 2014). Women's names are rarely seen on war memorials; Annie Allen, a volunteer at a convalescence hospital who died in 1919, on the Eccleshall, Staffordshire town memorial, is a rare exception. Nurses, serving in a professional capacity like Edith Cavell, who will be discussed below, or as a Voluntary Aid Detachment (VAD), like Annie Allen, or Vera Brittain (1933) held an anomalous position in war and hence in remembrance. Yet, it will be argued within media texts women found spaces to exert influence over who was remembered and how.

\section{Establishing patterns of commemoration in wartime media}

During the First World War, local and national media were creating knowledge in the Foucaudian (1980) sense about the war, the ways in which the conflict was understood, imagined and discussed. In so doing media provided the lexicon of possibilities from which the general public tried to understand the death, destruction and deprivation. Local newspapers carried lists of the fallen. Pages of portrait - style images of men who had died or were missing, dressed in their uniform were presented for local communities to remember, revere and feel gratitude towards. However, the local press remained uncensored during the conflict and its letters pages consequently became a cultural space in which otherwise voiceless individuals could speak. They articulated a range of views about the war and who should be commemorated. For example, in March 1915 MrsPitts, a mother of three in Evesham, Worcestershire, whose husband was shot at dawn, used the pages of the local newspaper to contest ideas about who should be remembered. She positioned her husband, like the lists of the fallen, as a victim of war and wrote to the Evesham Journal to quell rumours about his death. She explained that he had written to her in November and December 1914 complaining he was deaf, lost and struggling to find his regiment. She also published her final correspondence from him in the local newspaper.

In contrast, film was a national medium, although meaning was created by the location in which texts were consumed. Newsreels and short public information films were in many respects propaganda; they portrayed how the government wished the population to behave rather than the multiple, varied contradictory responses individuals had towards their circumstances in wartime. The government sponsored 'documentary' The Battle of the Somme was seen by 20 million in the first six weeks after its release in Autumn 
1916 (Reeves, 1997:15) but its selective and sometimes staged portrayal of the Western Front had led it to be catagorized as propaganda since (Badsey, 1983; Downing, 2016). Nevertheless, it provided visual imagesfor those on the home front, which complemented the personal narratives of soldiers they had met, on leave, injured or convalescing in Britain. Publicity encouraged audiences to see the film as a narrative in which their loved ones played a part. One journalist of theBirmingham Daily Post explained to readers whose sons and husbands would have been in the Worcestershire or Warwickshire regiments that: 'The pictures will make a great impression, for here is drama indeed: not the sophisticated work of professional players, but war, with all its grimness, horror, and tragedy, in which the actors are our own husbands, sons and brothers.' This local audience was encouraged tolook out for the appearance of their two local regiments taking part ' in the big push'. They were encouraged to notice the Warwicks having a meal in camp and the cheery Worcestershire's preparing their wire cutters beforean advance (5 September 1916). For those of the audience whose loved ones were missing or dead, viewing the Battle of the Somme could be an act of remembrance: their emotional reactions when they thought they spotted their lost relatives on the screen are well documented, as are their repeated attendances at the film (Reeves, 1997). The Battle of the Somme was not however the first film that played a role in constructing memories of the First World War.

The media's response to the German execution of the British nurse Edith Cavell in October 1915 in Saint-Gilles, Belgium firmly established their role in remembrance and commemoration. By the end of December a short eleven-minute, commemorative film was in cinemas across Britain entitled Nurse and Martyr. This, like most of the narratives of Cavell's life story that followed, struggled to contain her life story within discursive constructions of women as carers, vulnerable and in need of protection from men. It adopted two key strategies to do this: portraying Cavell as anultra-feminine young woman in her late twentiesor early thirties, some 25 years younger thanher age when executed but consistent with journalistic portrayals of wartime heroines during the conflict (Darrow, 2000: 110). It also silenced any mention of Cavell's spying activities. As Alison Fell points out: 'In popular representations, nurses at the front were not becoming honorary soldiers, they were extending their "feminine" influence, bringing the home/ domestic front to the soldiers' (2014: 109). The narrative of Nurse and Martyr maintains a focus on her domestic qualities, visually suggesting Cavell cares for the injured allied soldiers and seeks to returnto their worried families at home.

Even before the film was released Edith Cavell'sshooting had created a media outcry, which ithas been suggestedled to an increase in recruitment, particularlyin her hometown of Norwich (Pickles,2016). At the end of the film the words 'The blood of a martyr calls you' precede an image of Edith. Her arms are 
stretched out to the audience, entreating men to volunteer for the war effort, to avenge her martyrdom, and protect women undertaking their 'natural' roles nursing men. The title of the film was adopted when the censor insisted a direct reference to Cavell would be too political. Local newspapers, however, all referred to the film depicting 'in a reverent and faithful matter the life and martyrdom in Belgium of the late heroine Nurse Cavell' (Thanet Advertiser, 15 January 1916). The soldiers in the firing squad are unable to fire their guns directly at her; signifying the injustice of her execution and necessitating their commander kill Edith with his pistol. As Katie Pickles (2016) points out, this portrayal of her death reached mythical proportions in the years that followed. It provides another example of how film and local newspapers, even during the conflict, gave women a voice in articulating, stretching and renegotiating discourses of martyrdom and trauma, shaping who should be seen as victims of war.

\section{The interwar years: contesting practices of remembrance}

In the immediate post-war period newsreels and newspapers provided a link between individual, local and national practices of remembrance; if the media was an institution with the scope to communicate, reinforce and evencreate national memories, it also mitigated against the creation of a single shared national, cultural memory of the conflict. When Edith Cavell's exhumed body was returned to Britain in May 1919, the funeral cortege's progress from Belgium to services at both Westminster Abbey and her hometown of Norwich was shown on newsreels and reported in the press, as was the unveiling of a commemorative statue of her in 1920. The film of the cortege's journey visually linked home and battlefronts and made an individual's death part of national commemoration, as the journey of the UnknownSoldier, from France to London where a ceremony and funeral took place which featured in the Pathe News film for Armistice Day in 1920 also did. As Julie-Marie Strange has pointed out 'the war questioned certainties concerning ownership of the corpse' (2005: 266), assoldiers bodies were not returned home to their loved ones. The Unknown Soldier was deliberately anonymous, but both he and Cavell were symbolic bodies representing all soldiers and nurses who were victims of war but whose 'families were confronted with the dispossession of the dead' (Strange, 2005: 266). The Pathenews Armistice Day filmended with what is now aniconic ritual of the royal family laying wreaths at the Cenotaph. Thus the film conveyed into public consciousnessiconic images of national commemoration, thestonemonumentat the centre of government in Whitehall, that Jay Winter has described as both sites of memoryand sites of mourning (Winter, 1998). 
ScreeningArmisticeDayceremoniesincinemasfacilitated wide participationinsuchevents, albeit withatime lag; broadcastingtheFestival of Remembrance and the service from the cenotaph on Armistice Day and the two minutes 
silence enabled the ceremonies to become truly national events experienced in ordinary people's homes. Whilst Jay Winter argues that the two minutes silence can almost be seen as a 'secularized prayer' (1999: 3). Mass Observation Day Diaries from 1937 indicate that radio was entrenched in domestic life, listened to whilst many women were engaged inchores, cleaning the houseand preparing food (Andrews, 2012). Listening to commemorativeactivities within the home placed them within the profane, rather than the sacred (Durkheim 1976), even more so when incorporated into the evening's entertainment. The Festival of Remembrance held annuallyat the Royal Albert Hall since 1923, was initiallymodernistas opposed to populist in tone (Mansell, 2009). The original concert featured Foulds' World Requiem, and was advertised as 'a festival of faith, not of victory'. But in 1927 the combined forces of the Daily Express newspaper and the BBC turned it into a more populist broadcast production with pageants and popular songs such as Pack up Your Troubles, and Tipperary included alongside The Last Post and the national anthem (Mansell, 2009). The wireless, transformed an event, which thousands of people could attend into a national event in which millions participated. Like much early broadcasting and film the festival owed a debt to the music hall (Kift,1996) and as such would not have been at variance with the Saturday night listening patterns developed in this era. As they listened to the Festival of Remembrance, or the Cenotaph ceremony on Armistice Day the public had a plethora of images to draw upon, newsreelsfrom the war and since, the Battle of the Somme, subsequentfilms and the press coverage to interweave with personal and family narratives. Hence, as Lucy Noakes (2015) analysis of responses to Armistice Day in Mass Observation Diaries from 1937 to 1941 suggests, individuals engaged with the practices of remembrance in varied and gendered ways.

The Cenotaph, the Tomb of the Unknown Soldier and BBC's broadcasts operating as sites of memory. They all contribute to the construction of national and imperial identities (Mosse, 1991; Winter, 1995; Macleod, 2013; Gregory, 2014), running alongside more locally specific memories and memorials (Connelly, 2002; Gaffney, 1998; Switzer, 2007). Local newspapers suggest women had a voice in shaping remembrance practices at this local level. When the British Legion poppy was introduced in 1921 (lles, 2008) the press was used to drum up support; the Mayoress of Hull wrote to her local paper in 1922 seeking volunteers to assist in the selling of the 22,000 poppies the town had ordered (Hull Daily Mail, 6 November 1922). Local papers also appealed to community pride by reporting funds procured from selling poppies. In 1922, for example, The Hampshire Telegraph and Post gave a careful summary of sums donated and raised in various towns and villages in the county. Havant was described as having collected the excellent sum of $£ 750$ s $5 d$, whilst the smaller adjacent town of Emsworth realized only $£ 4313 \mathrm{~s} 7 \mathrm{~d}$ (17 November 1922). The competitive tone that crept into this reporting echoes the local newspapers' recording of the numbers of recruitsfrom different towns 
and villages inthe earlymonths of thewar. Butperhaps justas significantlyit mirrors the coverage of tallies for women's fundraising and charitable activities, such as the number of eggs collected for the wounded soldiers, which became signifiers of local patriotism during the war. Images of commemorative events in newspaperswere dominated by the iconography of remembrance sculpture, but if the Cenotaph featured in the national press, local press had their own regionally specific emblems of their identity. The Western Morning News and Daily Gazette on 11 November 1933, dedicated its front page to an image of the City War memorial in Northernhay, Exeter under the heading Remembrance 1933. The figurative sculpture of Victory was above a cross with bronze figures representing war and included a soldier, a sailor on the hull of a ship, a prisoner of war, and a VAD nurse in uniform holding a bandage. Unlike the cenotaph, the memories of wartime sacrifice evoked here deliberately included women.

In Nothernhay's figurative sculpture of war the enemy was invisible, hidden and silenced, enabling the ideas of war and the actions of those involved in it to be purified. This was not the case in the 1928 film of Edith Cavell's life, entitled Dawn. Its potential release met with resistance as the British government was seeking to establish a new and more co-operative working relationship with Germany. The British Board of Film Censors initially refused to give Dawn a certificate and explained in the national and local press that in their opinion 'the theme of this film renders its exhibition in this country inexpedient in the present circumstances' (Nottingham Journal, 21 February 1928). Politicians and literary heavyweights including the Foreign Secretary Austin Chamberlain and the German Ambassador waded into the debate and opposition also came from members of Edith Cavell's own family who regarded the film as likely to encourage hatred towards Germany (Nottingham Journal, 21 February 1928). When the film was finally released some of the more controversial elements, including most of the death sequence, had been removed.

If the gestalt of the 1920s was to look back, commemorating 'the war to end all wars', many in the 1930 s feared another conflict looming, as internal memos of the BBC planning for Armistice Day acknowledged (BBCWA). However, the Corporation, under Director - General John Reith, remaineda reverential organizationavoiding political controversyor scaremongering, aiming to educate, informand entertain(Briggs, 1985; Tracey, 2000). When the Women's Co-operative Guild's introduced the white poppy in 1933, as a symbol of the wearer's commitment to peace and avoiding another war, it was in the frenzy of letters to the local press that the controversyraged. The Birmingham Gazette dedicated a number of column inches to discussion. MrJ. Smedley - Crooke MPfor the Deritend constituency of Birmingham explained he would be asking the government to make the sale of white, as opposed to the traditional red, poppies on Armistice Day illegal. 
Their sale, however, met with approval from the Burton-on-Trent Women's Section of the British Legion. In other areas their very existence was anathema. MrsSmee, the honorary secretary of the Metropolitan Area Committee of the Women'sSection of the British Legion expostulated: 'It was women's job to keep peace, but peace with honour. They had got to see that the last war was not forgotten, and if they taught their children what littlewasto be gained by war there would not beanother war.'She had no objection to white poppiesitappeared butnot sold on Armistice Day (4 October 1933). And Sister Dora Henson penned a letter to the Dover Express to express her opposition to white poppies ending with pronouncement that 'To have any other sale but the red Flanders poppy on November 11th would appear to be an insult to the Flanders Poppy and all it stands for' (3 November 1933).

Historians have discussed how in the 1930s social divisions, exemplified by the uneven distribution of unemployment, housing, maternal mortality and child welfare, led to political demonstrations from left and right. In October 1936 both the march of the British Union of Fascists through the East End ending in a riot and the Jarrow Hunger March took place (Webster, 1982; Constantine, 2006; Gardiner, 2011). Political divisions included disagreement over military responses towards foreign countries' aggression. In February 1933 the Oxford Union debate motion ('that this House will in no circumstances fight for its King and Country') was carried by 275 votes to 153 and followed by fierce condemnation in the Daily Express and DailyTelegraph (Ceadel, 1979). The next year, a letter to The Guardian by DickShepherd, Canon of St Paul's Cathedral, asking men to pledge never to support war, precipitated the formation of the Peace Pledge Union (Rigby, 1999).

Against this row, turmoil erupted over Armistice Day within the pages of the Lincolnshire Echo. The British Legion and representatives of the armed forces apparently decided to boycott the Armistice Day Service as the Mayorelect was reputed to have beena conscientious objector during the First World War. Many readers were of the opinion that the Mayor-elect should not be allowed to attend or at least lay a wreath at the town war memorial (LincolnshireEcho, 140ctober 1933). Women were active in the inter-war peace movements (Liddington,1989) and when during the dispute a magistrate described the armed forces as a 'brass hats and bayonets brigade who encouraged militarism', she and her supporters were labelled Bolshevists and linked to the No More War Movement. One vicar saw the absence of military parades on Armistice Day as of 'comfort to traitors and conscientious objectors and those who do not care a rap for their country' whilst another suggested a compromise allowing only those who had served in the Great War and ex-military to take part and some proposed the military should not carryarms F.CSawyer wrote to congratulate the councilon 'banning' 
military display, explaining: 'Tome itseems definitely indecent at a service in memory of dead men to make a parade of the very weapons which killed them and which will very possibly kill quite a lot more of us in the near future' (Lincolnshire Echo, 14 October 1933). As the debate became increasingly heated, the intolerance and the animosity was criticized and it was suggested those who had died should be remembered in the peace they had fought for. Remembrance Sunday, itself, seemed momentarily to silence antagonism in the city, and the same newspaper carried a headline entitled: 'Lincoln Unites in Homage to Glorious Dead: Controversiesforgotten ingreat silence at city war memorial' (LincolnEcho,14 November 1933).

The media sometimes side-stepped controversy by emphasizing the important charitable work poppy sales funded nationally. The Biddleswade Chronicle and Bedfordshire Gazette gave a detailed account of the 'three hundred and sixty-three severely disabled ex-Service men employed in the British Legion poppy factory' (10 November 1934). Likewise, in November 1939, when Britain was once again at war, Pathe news focused on the Queen's visit to the British Legion poppy factory, in Richmond, Greater London in their Armistice Day newsreel. The voice-over suggested that the British Legion Fund now had responsibility to care for this generation of fighters and the last. National ceremonies of remembrance ceased during the conflict but local events and poppy sales continued and expressions of disillusionment appeared in letters pages of the local press including a poem which asked: 'Have we broken our faith with those who died? Was it in vain their lives were sacrificed? (Warwickshire News and Chronicle, 10 November 1939). Others criticized this negativity and an editorial the Coventry Evening News argued: 'It is not we who have failed to maintain the peace that those menwon' (11 November 1939).

\section{First World War remembrance after the Second World War}

There was uncertainty about organizing the national calendar of remembrance and commemoration in the aftermath of the Second World War, and suggestions that VictoryinEurope or VictoryinJapananniversaries should replace Armistice Day. The ensuing consultation involved Commonwealth Governments, highlighting Remembrance Sunday's role in constructing Imperial rather than merely national identities. Representatives of the Christian churches favoured retaining the link between Remembrance Sunday and All Souls Day on the 2 November, as a day of mourning. The Prime Minister announced there would be no change in 1946, but debates rumbled into the 1950s and 1960s, with suggestions November weather was unsuitable for elderly veterans (Hansard, 1954). The war gave the BBC a renewed sense of confidence. The medium through which Churchill had addressed the nationand which was the purveyor of news to and from the fighting forces saw itself as the 
'voice of the nation', even the Commonwealth. (Briggs, 1985; Andrews, 2012). Tony Shaw argues the BBC 'established a tight working relationship with Whitehall during the fight against Nazism' (2006: 1355) which continued during the Cold War. Against this backdrop the televising of the Festival of Remembrance for the firsttime in 1950 was a tightly stage-managed event that brought together the Crown, the BBC, Church of England and The Royal British Legion. Itvisually institutionalized the Festival of Remembrance and reinforced it as a symbol of British cultural identity.

The Corporation sought to include the dead of both world wars and those who died in subsequentand ongoing conflicts in the Festival. This acknowledged the families whose sons had been called up for national service, peacekeeping in the Middle East or policing an empire slowly being dismantled. The BBC announcer at the 1950 Festival of Remembrance invited viewers to 'join the 5,000 Ex-Servicemen and women gathered from all parts of the country to pay homage to their fallen comrades of two world wars' (BBCWA). Speaking to a nation coming to terms with the old and new (Kynaston, 2010), the commentary described the festival as 'a tradition in our national life' and drew attention to another tradition of nationhood - the royal family (Brunt, 1992: 288). Communal singing of popular songs from both wars included: Pack up Your Troubles and White Cliffs of Dover, providing a sense of inclusive familiarity for two generations of soldiers and their families. As Noakes and Pattinsonargue cultural memories of the Second World War are bothfamilystories and publicacts commemoration (2013:3), the Festival watched by families in their homes, linked private and public memories and home and battlefronts. A pageant re-enacted the Durham Royal Garrison Artillery defence of the German shelling of Hartlepool on the 16 December 1914, when battleship attacks on Hartlepool, Scarborough and Whitby produced nearly 600 civilian casualties and over a hundred and thirty deaths. The Festival's version of the past was however selective, portraying civilians as protected bythe armed forces, not mentioning criticism in 1914 of the Navy for allowing German warships to get so close to the coast. The reference to First World WarZeppelin raids and a reminder that civilian deathsfrom bombing occurred inthis conflict sought to connectandmergeboth warsinto anational butunsustainablenarrative. The Festival of Remembrance continued to monopolize schedules before Remembrance Sunday. In 1956 a BBC Audience survey reported that $20 \%$ of the adult population and $54 \%$ of the viewing public watched what a civil servant described as a 'means of uniting, in a common bond, all those who wish to remember, at this time of year, the debt owed to the service men and women of two world wars' (BBCWA). But as Hilda Kean argues, to the generation growing up in 1950s and 1960s, the Second World War was 'the war' (2017). As the memory of this conflict becameentwined with and defined by the Holocaust (Noakesand Panttinson, 2013) it also 
increasingly began to be seen as Britain's good war (Calder, 1995). This as Connelly argues 'fundamentally altered people's memories of the Great War which by comparison seemed futile' (2002:8).

In the 1960s the BBC's 26-week television documentaryThe Great War (1964) was a televisual act of remembrance marking the 50th anniversary (Hanna, 2009), drawing upon interviews with veterans. Despite regularly attracting viewing figures of over 8 million for this attempt to portray a nuanced and complex history of the conflict, cultural memories of the conflict concentrated on mud, barbed wire, innocent or naïve, but well-meaning British Tommies forced to take part and led to their death by incompetent generals were gaining traction in Britain and were tenacious (Todman, 2014). They resurfaced again in Chilton's radio play The Long, Long Trail, later transferred to the stage and into a British comedy musical film entitled Oh What a Lovely War in 1969. The anti-establishment tone of these texts perhaps sat more comfortably with a younger generation who no longer undertook national service, lived in era when the last remnants of Empire were being dismantled, youth cultures were more prominent and troops patrolled the streets in Northern Ireland, a generation with an imaginative rather than actual investment in the First World War (Hirsch, 2008).

Narratives of the futility of the First World War focused on the masculine sphere of the battlefield and as veterans grew older the relevance of Remembrance Sunday was questioned and suggestions made that the 50th anniversary Armistice Day should be the last. The Aberdeen Press and Journal noted ex-servicemen had shown a distinct lack of interest in the Remembrance Sunday parade and their British Legion chairman announced: 'We will try it once more this Sunday. If there is not a turn-out future parades may be shelved' $(9$ November 1965). As many veterans, were becoming too old to march, local press recorded the plethora of different iterations of Remembrance Sunday ceremonies evolving, noting that Coventry Cathedral's service in 1969 was devoted to a study of race relations and how to avoid the horrors of discrimination (Coventry Evening Telegraph, 3 November 1969). The local press interrogation of practices of remembrance occurred in tandem with the emergence of second-wave feminism and included voices criticizing both women's marginalization from remembrance activities and the poverty of war widows. There were reports of British Legion Women's branches holding their own separate Remembrance Sunday ceremonies and complaints from war widows who could not access war memorials or about the war office's refusal to pay travel costs for a war-widow to attend her son'sfuneral when he was killed on active service in Germany (Birmingham Gazette, 4 September 1962). One war widow complained that her pension was less than her 
neighbours', whose husband was in prison, she both criticized the post-war welfare state and discursively linked the widow's plight to the 'husbands who were heroes not so long ago' (Coventry Evening Telegraph, 12 
November 1962).

The year after the first Women's Liberation Conference was held at Ruskin College, the War Widows' Association was formed precipitated by the actions of Laura Connelly, described as the 'widow of a military medal hero of the First World War' (Daily Mirror, 1 June 1972). ${ }^{2}$ She took a defiant stance in refusing to pay the $50 \%$ tax on her widow's pension, which was classified as unearned income. Debate raged in local and national press about this and non-commissioned officers' wives were labelled 'an army of forgotten warwidows' (AberdeenEvening Express, 8 November 1979). The War Widows Association adopted the practice of laying a wreath of white chrysanthemums in a private ceremony at the cenotaph on the Saturday before Remembrance Sunday, only to have it removed in advance of the official, national televized ceremony. This negation of the women's right to remember and be remembered was again criticized in local newspapers, but at the end of the decade the Newcastle Evening Chronicle celebrated the announcement that: 'For the North Eastern branch at least there will be no such humiliation. The war widows have accepted an invitation from the Lord Mayor of Newcastle to lay a wreath at the Civic Remembrance Service in Walden Square for the first time' (18 September 1980).

Aswomen'shistoryand people'shistory werechallenging cultural constructions of thepast(Schwarz,1993; Purvis, 1995; Iggers, 2005) thefirst episode of a five-part television dramatization of Vera Brittain's Testament of Youth (BBC2) was broadcast in theweekbefore Remembrance Sunday in 1979 Richard Badenhausen suggests Brittain's original text was both an autobiography of her First World war experiences as a volunteer nurse and 'a memorial to her lost male companions and their silenced voice' (2003: 431). However the television adaptation is unashamedly a woman's narrative of war, visually located in female spaces: the home, the hospital ward and women's college at Oxford, prioritizing her feminist challenges to women's role in the family, marriage and society. Archive newsreel punctuates the narrative, underlining its truth claims and including in the opening images of 1913, a portrayal of the suffragette Emmeline Pankhurst being arrested. The narrative does not suggest that war liberated women, but rather that woman and those on the home front also suffered. The television drama and the war widow's campaigns pulled memories of war away from the battlefield, enabling discourses of remembrance to begin to stretch from portraying soldiers as victims of war to seeing their families also as victims (Winter,2006a,b: 6; Andrews, 2011), which culminated in the introduction of the Elizabeth Cross for the families of the bereaved in 2009.3 


\section{Multiple voices: the new media age}

Technological developments in the last quarter of the twentieth century, the introduction of colour, cable and satellite television and the internet, heralded an era of media saturation and multiple new platforms through which remembrance could engage popular audiences. Colour television increased the visual impact and emotional intensity of the dropping of thousands of red poppy petals as a finale to the Festival of Remembrance whilst broadcast media news reported on British armed forces' progress during the Falklands War in 1982 with a new immediacy (Philo, 2014). The introduction of a plethora of new channels through which to digitize the past in conjunction with the memory boom (Winter, 2006a,b) that emerged at the end of the twentieth century invigorated enthusiasm and interest in the First World War. The media continued to provide a plethora of spaces and places for people to reworkideas of remembrance, to voice alternative views and challengeanyinstitutionalization of remembranceincludinganongoing controversyoverwearingwhitepoppies(AdvertiserandGazette, 13 November 1986). Alternatively letters to the press suggested new alliances, including the assertion that both those who marched in remembrance parades and the campaigners against nuclear weapons at Greenham Common Peace Camp shared their desire for peace (The Journal, 14 November 1983).

This competitive multichannel broadcasting environment inclined Institutions of broadcasting to harness the gravitas of remembrance to give them legitimacy. The most well-known example of this is the BBC's comedy series BlackAdder goes Forth, broadcast from 29 of September to 2 November 1989. In the dramatic final scene the main characters go over the top on the Western Front. The four main characters, but not their general, charge in slow motion into the chaos of the battlefield and their death is signified by a visual fade to show a poppy field. This narrative confirmed prevailing discourses of the futility of the First World War (Badsey, 2002) and sought an emotional response from audiences. The series won the British Academy Television Award for the Best Comedy Series in 1989 and gained an iconic status in public consciousness, being used as a teaching tool in schools to encourage engagement with the history of the conflict (Pennell, 2014, 2016). ${ }^{4}$ However, it was the media's engagement with the ninetieth anniversary of First World War, set against British involvement the wars in both Iraq and Afghan, which evoked the most poignant interplay between past and present conflicts in numerous programmes surrounding Remembrance Sunday. The broadcast media's language of personalization, celebrity and confessional culture (for example, in the drama My Boy Jack (2007), simultaneously evoked an emotional response to death in the First World War and contemporary conflict whilst also critiquing the politics of conflicts (Andrews, 2011). In 
doing so they laid the foundations for the media's coverage of the First World Waratatime whenthe BBC faced questionsover its roleand monopoly of the licencefee funds by politiciansand the press. ${ }^{5}$

The Corporation embraced the centenary to legitimate its status as the predominant public service broadcaster in Britain and by 2014 had commissioned 1400 First World War related programmes, a significant cultural intervention in constructing memories of the conflict. The independent, non-partisan think-tank, British Futures 2016 survey noted: 'More than a third of people (37\%) had seen information about the First World War Centenary on television in the month of our survey [...] 15\% had seen coverage ina newspaper and $13 \%$ had heard through word of mouth and $11 \%$ had encountered the Centenary online and $10 \%$ had heard information on the radio (Hough, et al.,2017: 22). Whilst the BBC memorials on the 50th anniversary had centred on soldiers, the centenary included those on the home front whose lives were disrupted or destroyed by war.

The Great War Diaries (2014), told the story of the conflict through the words of diaries, letters and memoirs of men and women from Germany, France, Russia, Austria - Hungary and the USA. This international drama series, of 4 episodes, interspersed archival footage and re-enactment. The broadcast media's reception in the home has arguably domesticated and feminized its content (Andrews, 2012), hence this series also featured the heroism of women and included a nurse, a welfare worker in a munitions factory, a mother, a girl soldier and a young girl in France. But relying on what are often referred to as ego-documents, inevitably privileged the narratives of the better off, it was the fictional Radio 4 drama Home Front that documented the multiplicity of experiences of ordinary people during the conflict. Its 15 series, each with approximately 40 episodes, was broadcast between 4 August 2014 and November 2018. It charted the lives of 30 characters at three locations: Folkestone, Devon and Tyneside, its narrative heart lay with, Kitty, a working-class girl whose life and love of a German waiter was turned upside down by thewar. The podcasts, available online forten years, create a new kind of media legacy. The fictional life of women's mundane, everyday concerns including food and family do not necessarily conform to audience expectations of war; but like the Great WarDiaries, Home Fronthas stretched and reworked media remembrance, extending ideas of who should be remembered and how, in relation to gender. 
The significance of this programming should not however be overstated; cultural interventions such as, the National Memorial Arboretum, officially opened in 2001, Armed Forces Day introduced in 2006, Help for Heroes formed in 2007, the Invictus Games initiated in 2014 have raised the profile of the heroic, stoic British Tommy (McCartney, 2014; Andrews, 2017). Sainsbury's commercial annexing of this icon in their Christmas advert in 2014 offended the public and sent historians apoplectic. Made in conjunction with The Royal British Legion, the advert portrayed a British Tommy giving a German soldier a bar of Sainsbury's chocolate in no man's land during the mythical 1914 Christmas Day football match. It ended with the words Christmas is for Sharing and the Sainsbury's insignia. 727 people complained to the Advertising Standards Authority, who nevertheless ruled it was unlikely to cause serious harm or offence. In the commentary in newspaper and on social media, it was the blatant commercialization that upset people. Thirty years earlier Paul McCartney had also used the myth of the Christmas day football match in a pop video to promote his song Pipes of Peace (1983) with little criticism. However during the First World War centenary, setagainsta backdrop of a more populistantiestablishment political gestalt, harnessing remembranceto blatant commercialism of two established institutions led to distain. Social media provided a platform to critique remembrance just as local papers did in the past. Thus The Royal British Legion's commercial activities including the sale of poppy onesiesled to the sarcastic tweet that there was'No need to be chilly as u \#Respect the \#FrozenFallen who perished in the icy tomb of the Eastern Front! Cuddle up in these his \& her onesies!' pic.twitter.com/Qoip1Uzb3K (accessed 4 July2018).

\section{Conclusion}

Since the First World WartheUK media has played a significant role in the co-creation of remembrance, embedding iconic images of national commemoration in the public consciousness and entwining together individual, local and national practices of remembrance. A historical analysis of some of this media provides evidence of the role old and new media plays in contesting remembrance and the ways in which, at different cultural moments, have enabled women's memories and concerns to find a voice in remembrance. The long-term significance of this on cultural memories remains an area for further study. Likewise as the commemoration of the First World WarCentenary comes its end, there is a need to question just how inclusive remembrance has really become and whether Britain's fascination and pre-occupation with memories and remembrance of the First World War is finally beginning to wane. 


\section{Endnotes}

1. The English Defense Leaguewereforexample arrested near an Armistice Day Ceremony in Londonastherewere concerns that they headed towards anti-capitalist 'Occupy London' group camped around St Paul's Cathedral seehttps://www.telegraph.co.uk/news/uknews/crime/8884583/170-members-of-English-Defence-League-arrested-nearCenotaph-in-London.html [accessed 2 March 2018). In the same year a Muslim protester was prosecuted for setting light to two poppies see - https://www.theguardian.com/uk/2011/mar/07/muslim-extremist-finedfor-poppy-burning (accessed 2 March 2018).

2. For a more detailed and nuanced exploration of the War Widow's disputes see Logmas (1995).

3. The Elizabeth Crossis awarded in Britain to the next of kin of those in the armed forces who have been killed in action ora terrorist attack since the Second World War.

4. The TES provided worksheets and teachers notes for using Blackadder in schools, although the practice evoked controversy see for example thttps://www.stephenperse.com/the-great-blackadder-debate https://schoolhistory.co.uk/forum/index.php?showtopic=9700 (accessed 4 June 2018).

5. Therehasbeenanextensivedialogueinthepressbybothpoliticians,economistsandmediapunditsabouttheBBClicense feesince 2007

\section{References}

Aberdeen Press and Journal, 9 November 1965.

Andrews,M.2011.MediatingRemembrance:PersonalizationandCelebrityinTelevision'sDomesticRemembrance.Journalof War\&Culture Studies, 4(3), 357-70.

Andrews, M. 2012. Domesticating the Airwaves: Broadcasting, Domesticity and Femininity. London: Bloomsbury Academic. Andrews, M. 2017. Remembranceand theWorking ClassSoldierHero in AusterityBritain. In:Cultural PoliticsintheAgeofAusterity. London: Routledge, pp. 47-66[AQ12].

Ang,I.2006. LivingRoom Wars:RethinkingMediaAudiences.London:

Routledge. Archival Sources

Ashcroft, R. \& Bevir, M. 2016. Pluralism, National Identity and Citizenship: Britain after Brexit. The Political Quarterly, $87(3), 355-59$.

Badenhausen, R. 2003. Mourning through Memoir: Trauma, Testimony, and Community in Vera Brittain's "Testament of Youth". Twentieth Century Literature, 49(4), 421-48.

Badsey, S.D. 1983. Battle of the Somme: British War-Propaganda. Historical Journal of Film, Radio and Television, 3(2), 99115.

Badsey, S. 2002. The Great War. Historical Journal of Film, Radio and Television. 22(1): 41.

Baer, A. 2001. Consuming History and Memory through Mass Media Products. European Journal of Cultural Studies, 4(4), 491-501.

Bailey,P.1986.MusicHall:TheBusinessofPleasure(Vol.1).London:Open

UniversityPress. BBCWritten Archives (BBCWA) Files on Festival of

Remembrance 1930-1950s.

http://www.bbc.co.uk/informationandarchives/access archives/bbc written archives centre Archives visited 4 June 2015.

Belam, M. 2017. JD Wetherspoon denies poppy ban after Twitter hoax causes uproar. The Guardian, 27 October 2017. Berry, D. ed. 2017. Cultural Politics in the Age of Austerity. London: Taylor \& Francis.

The Biddleswade Chronicle and Bedfordshire Gazette, 26 October 1934. 
Birmingham Daily Post, 5 September 1916.

Birmingham Gazette, 1 November 1933.

Briggs, A. 1985. The BBC: The First Fifty Years. Oxford: Oxford University Press, pp. 249-51.

Brittain, V.M. 1933. Testament of Youth: An Autobiographical Study of the Years 1900-1925. London: Gollancz.

Brunt, R.1992.A'DivineGiftto Inspire'? PopularCultural Representation, Nationhoodand theBritish Monarchy. In:D.Strinatiand S.Wagg, eds. Come on Down? Popular Media Culture in Post-War Britain, pp. 285-301.

Calder, A. 1995. Britain's Good War? History Today, 45(5), 55-61.

Calder, A. 2017. The Scottish National War Memorial. In Memory and Memorials. London: Routledge. 73-86.

Ceadel,M.1979. “TheKingand CountryDebate,1933:StudentPolitics, PacifismandtheDictators”. TheHistoricalJournal.22(2), 397-422.

Connelly,M.2002.TheGreatWar,MemoryandRitual:Commemorationinthe CityandEastLondon,1916-1939(Vol.23).

Martlesham:Boydell \& Brewer.

Constantine, S. 2006. Social Conditions in Britain 1918-1939. London: Routledge.

Coventry Evening Telegraph, 5 November 1969

Cover,R.2006.AudienceInter/Active:InteractiveMedia,NarrativeControland ReconceivingAudienceHistory.NewMedia\& Society,8(1), 139-58.

Curran, J. 2012. Media and Power. London: Routledge.

Darrow, M.H. 2000. French Women and the First World War: War Stories of the Home Front. London: Bloomsbury Academic.

Dover Express, 3 November 1933.

Downing, T. 2016. Battle of the Somme: The Making of the 1916 Propaganda Film. Historian, (129).

Evesham Journal, 6 March 1915.

Fell, A.S. 2014. Remembering Frenchand British FirstWorldWarHeroines. In:C. HammerleandO. Uberegger, eds. Genderand the First World War. London: Palgrave Macmillan, pp. 108-126.

Foucault,M.1980. Power/Knowledge:SelectedInterviewsandotherWritings,1972-1977.

Pantheon.[AQ18] Gaffney,A.1998.Aftermath:RememberingtheGreatWarinWales(Vol.14).Cardiff:

UniversityofWalesPress.

Gardiner,J.,2011,August. 'Searching fortheGleam': Finding SolutionstothePoliticaland Social Problems of 1930s Britain. History Workshop Journal, 72 (1),103-17.

Goodwin, A. 1992. Dancing inthe Distraction Factory: Music Television and PopularCulture. Minneapolis:University of Minnesota Press.

Gregory, A. 2014. The Silence of Memory: Armistice Day, 1919-1946. London: Bloomsbury Publishing.

Hall,S.1981. NotesonDeconstructing 'thePopular'. In:R.Samuel,ed.People's HistoryandSocialist Theory(RoutledgeRevivals).

London: Routledge. 
Hampshire Telegraph, 17 November 1922.

Hancock Edith the drinks business website

https://www.thedrinksbusiness.com/2017/10/wetherspoons-says-it-will-not-enforce-poppy-ban-after-thousands-fallfor-twitter-hoax/

Hanna, E. 2009. The Great WarontheSmall Screen:Representingthe First World Warin Contemporary Britain.Edinburgh University Press.

[AQ22]

Hansard https://api.parliament.uk/historic-hansard/commons 1945-1970 accessed 2 July 2018.

Hess,A.2007. In Digital Remembrance:VernacularMemoryand the Rhetorical Construction ofWeb Memorials.

Media, Culture\& Society, 29(5), 812-30.

Hobolt, S.B. 2016. The Brexit Vote: A Divided Nation, A Divided Continent. Journal of European Public Policy, 23(9), 1259-77.

Hough,M., Ballinger,S., \& Katwala, S.2017 A CentenaryShared:Tracking PublicAttitudesforthe FirstWorldWar Centenary2013-2016.

British Futures [accessed 4 June 2018]. Available at: <http://www.britishfuture.org/publication/a-centenaryshared-ww1-tracker/>

Hull Daily Mail, 6 November 1922.

Huston, N.1983. Tales of War, Tears ofWomen. Women's Studies

International Forum, 5,271-95. Iggers, G.G.2005. Historiography in the

Twentieth Century. History and Theory, 44(3), 469-76. Iles, J. 2008. In

remembrance: the Flanders poppy. Mortality, 13(3), 201-21.

Kean, H.2017. The GreatCatand Dog Massacre: The RealStoryofWorld War Two's Unknown Tragedy. Chicago:University ofChicago Press.

Keren, M.\&Herwig, H.H. eds.2009.WarMemoryand PopularCulture:EssaysonModes ofRemembranceand Commemoration.Jefferson: McFarland.

Kift, D., 1996. The Victorian Music Hall: Culture, Class, and Conflict. Cambridge: Cambridge University Press.

King, A. 2010. The Afghan Warand 'Postmodern' Memory:Commemorationand the Dead of Helmand 1. The British Journal of Sociology, 61(1), 1-25.

Kynaston, D. 2010. Family Britain, 1951-1957. London: Bloomsbury Publishing.

Lamb, C. 1994. The Minnie Pit Disaster. Staffordshire: Miles Green Press.

Landsberg, A. 2004. Prosthetic Memory: The Transformation of American Remembrance in the Age of Mass Culture.

Columbia: Columbia University Press.

Lee, J.2006 A Nurse and a Soldier: Gender, Class and National Identity in the First World War Adventures of Grace McDougall and Flora Sandes. Women's History Review, 15(1), 83-103[AQ20].

Liddington, J. 1989. The Long Road to Greenham: Feminism and Anti-militarism in Britain Since 1820. London: Virago Press.

Lincolnshire Echo, 9 October - 10 November 1933.

Local Archival Newspapers www.britishnewspaperarchive.co.u accessed January - March 2018.

Lomas, J. 1995. War Widows in British Society 1914-1990 (unpublished thesis, Staffordshire University).

Macleod, J.2013. Britishnessand Commemoration:National Memorials to the First World Warin Britain and Ireland.

JournalofContemporary History, 48(4), 647-65.

Mansell, J.G. 2009. Musical Modernity and Contested Commemoration at the Festival of Remembrance, 1923-1927. The Historical Journal, 52(2), 433-54.

McCartney, H.B. 2014. The First World War Soldier and his Contemporary Image in Britain. International Affairs, 90(2), 299-315. 
Moriarty, C. 1999. The Material Culture of Great War Remembrance. Journal of Contemporary History, 34(4), 65362.

Mosse, G.L. 1991. Fallen Soldiers: Reshaping the Memory of the World Wars. Oxford: Oxford University Press.

Neiger, M., Meyers, O.\&Zandberg, E. eds.2011. On Media Memory:Collective Memoryina New Media Age. New York City:Springer.

Noakes, L.2015.A Broken Silence? Mass Observation, Armistice Day and 'everyday life' in Britain 1937-1941.Journal ofEuropeanStudies, 45(4), 331-46.

Noakes, L. \& Pattinson, J. eds. 2013. British Cultural Memory and the Second World War. London: A\&C Black. Nottingham Journal, 21 February 1928.

Pathe News online https://www.britishpathe.com accessed 2-19 February 2018

Pennell, C. 2014. On the Frontlines of Teaching the History of the First World War. Teaching History, (155), 34.

Pennell,C.2016. Learning Lessonsfrom War? Inclusions and Exclusionsin Teaching FirstWorldWarHistoryin English SecondarySchools.

History \& Memory, 28(1), 36-70.

Pentzold, C. 2011. Digital Networked Media and Social Memory. Theoretical Foundationsand Implications.Aurora. Revistade Arte, Mídiae Política, (10), 72-89.

Philo,G. 2014. The Glasgow Media Group Reader, Vol. II:Industry, Economy, Warand

Politics. London: Routledge. Pickles, K.2016.Transnational Outrage:TheDeathand

CommemorationofEdith Cavell. New YorkCity:Springer. Purvis, J. 1995. Women's

History in Britain: An Overview. European Journal of Women's Studies, 2(1), 7-19. 
Reeves, N. 1997.Cinema, Spectatorship and Propaganda:'Battle oftheSomme'(1916) andits Contemporary Audience. HistoricalJournal of Film, Radio and Television, 17(1), 5-28.

Reynolds, G. 2015. The 5 worst radio moments of 2015 - The Telegraph https://www.telegraph.co.uk/radio/what-to ... to/the-5-worst-radio-moments-of-2015 15 Dec 2015

Rigby, A. 1999. The Peace Pledge Union: From Peace to War 1936-1945. In:P. Brock and T.P. Socknat, eds. Challenge to Mars: Pacifism from 1918 to 1945. Toronto: University of Toronto Press, pp. 169-85.

Schwartz, B. 1991. Social Change and Collective Memory: The Democratization of George Washington. American Sociological Review, 221-36.

[AQ25]

Schwarz, B. 1993. History on the Move: Reflections on History Workshop. Radical History Review, 1993(57), 20320.

Shaw, T.2006. The BBC, theState and Cold WarCulture: The Case of Television's the War Game (1965). The English Historical Review, 121(494), 1351-84.

Snow, J. 2006. https://www.channel4.com/news/by/jon-snow/blogs/wear-poppy-air 8 November 2006.

Strange, J.M. 2005. Death, Grief and Poverty in Britain, 1870-1914 (Vol. 6). Cambridge: Cambridge

University Press. Switzer, C.2007. Unionists and GreatWarCommemoration in the North of Ireland 1914-

1918. Dublin:IrishAcademicPress. Thanet Advertiser, 15 January 1916.

Todman, D. 2014. The Great War: Myth and Memory. London: A\&C Black.

Tracey, M.2000. The BBCand the General Strike: May 1926. In:E.Buscombe, ed. British Television:AReader. Oxford:

OxfordUniversityPress, 84-102.

Warwickshire News and Chronicle, 14 November 1939.

Webster, C. 1982. Healthy or hungry thirties? In: History Workshop. Editorial Collective, History Workshop, Ruskin College. pp. 110-29.

Western Morning News and Daily Gazette, 11 November 1933.

Williams, K. 2009. Read All About It! A History of the British Newspaper. London: Routledge.

Winter, J. 1998. Sites ofMemory, Sites of Mourning:The GreatWarin European Cultural History. Cambridge:Cambridge University Press.

Winter, J. 1999. Remembrance and Redemption. Harvard Design Magazine, 9.

Winter, J.2001.The Generation of Memory:Reflectionsonthe"MemoryBoom" inContemporaryHistorical Studies.

CanadianMilitaryHistory, 10 (3), 5.

Winter, J. 2006a. Notes on the Memory Boom. In: D. Bell, ed. Memory, Trauma and World Politics. New York City: Springer. 54-73.

Winter,J.M.2006b.Remembering War:The GreatWarbetweenMemoryand Historyinthe Twentieth Century.London:Yale University Press. Worcestershire Archives and Archeological Society (WAAS) - Bilston St Leonard's C.E School D836/3 1913-1919.

Zhao, H. \& Liu, J. 2015. Social Media and Collective Remembrance: The Debate over China's Great Famine on Weibo. China Perspectives, (1),

41-57.

\section{Notes on contributor}

Maggie Andrews is Professor of Cultural History at the University of Worcester; she writes, researches and broadcasts on twentieth-century British Women's History. Her publications include The Acceptable Face of Feminism: The Women's Institute Movement 1915-1960 (2015 and 1997), Femininity and Feminism: A Reader on Women and the Media since the 1900s (2014), The Home Front: Images, Myths and Forgotten Experiences (2014). She is the 
historical consultant to the Radio 4 Series Home Fronts and a Co-Investigator for the AHRC funded Voices of War and Peace World War One Engagement Centre.

Correspondence to: MaggieAndrews, Institute of Humanities, University of Worcester,StJohn'sCampus, HenwickGrove, WorcesterWR26AJ, UK. Email:Maggie.andrews@worc.ac.uk 